\title{
A Review on Natural Sources of Antimalarials: Fungi and Plants
}

\author{
Tehzeeb ${ }^{1, *}$, Dhanabalan ${ }^{2}$ \\ 'Rathnavel Subramaniam College of Arts and Science, Sulur, Tamil Nadu, INDIA. \\ ${ }^{2}$ Department of Microbiology, Rathnavel Subramaniam College of Arts and Science, Sulur, Tamil Nadu, INDIA.
}

\begin{abstract}
Recent progress in drug discovery in past decades reduced the high level of pain experienced due to infectious diseases by humans. A significant impact has been made on developing novel antimicrobial agents but is failing regularly due to development of resistance to drugs by the parasite or microbe. A continuing need of antimicrobials is there to protect humans from resistant microbes from different sources such as semisynthetic sources, synthetic and natural sources. Research in developing natural antimicrobials such as plant and fungal sources is still in its initial stages. In this review, we have concentrated on devastating disease malaria which is seen in several parts of world. Even though there are newly developed antimalarial artemisinin based combination therapy, recent reports are suggesting that resistance may also develop soon against the newer artemesinin products. Our search for literature and survey for natural antimicrobials motivated us to give concern to fungal source as promising
\end{abstract}

antimalarial and most unexplored source for the same. This review throws light on recent reports on disease malaria, causative species and outline of its lifecycle, targets of drug action and mainly the fungal sources of antimalarial.

Key words: Natural antimicrobials, Plants, Fungi, Secondary metabolites, Microbial resistance, Malaria and antimalarial.

\section{Correspondence}

Mrs. Tehzeeb

Research Scholar, RVS College of Arts and Sciences, Sulur-641402, Tamil Nadu, INDIA

Phone no: +919384769722

Email: tahirisha1011@gmail.com

DOI: 10.5330/ijpi.2020.4.74

\section{INTRODUCTION}

Diseases in humans are majorly two types - Metabolic and Infectious diseases. The major type of disease is infectious, caused due to microbes such as bacteria, fungi, viruses and protozoan parasites. Among the parasites or microbes bacteria accounts for major part of infectious disease. Millions of people are affected due to these infectious diseases. Affected people include mainly the poor people in developing countries due to unhygienic conditions. Diseases among poor may contribute to prolonged illness caused due to drug resistant pathogen. ${ }^{1}$ Pathogens faced by humans are resistant to even at least one of existing antimicrobial agent. The steady increase in evolution of drug resistant pathogen annually has been a cause of continuous demand for the development of novel effective antimicrobial drugs. ${ }^{2}$

Drugs developed against infectious disease have been developed as synthetic products and natural products in origin. Antimicrobial agents derived from microbes generally causes from fungi are secondary metabolites. Fungi represent one of the largest group of living world distributed across the length and breadth of the world.

Antimicrobial drugs are available in high quantity from natural products rather than from synthetic products. Natural antimicrobials forms two thirds of prevailing antibiotics and also forms half of drugs used in the treatment of cancer. ${ }^{3}$ Diversity of molecules synthesized by fungi is more and are therapeutically useful chunk of natural antimicrobials. Most important use of fungi includes production of antimicrobial substances such as secondary metabolites which are inhibitory or deleterious to other microbes. They are used to treat diseases caused due to microbes by varied mechanisms of actions and with a high degree of specificity to target sites of pathogens. Mechanism of antimicrobial action of secondary metabolites from fungi includes cell wall synthesis inhibition - Vancomycin, Bacitracin and Penicillin, disruption of cell membrane- Polymyxin B and Colistin, Protein synthesis- Tetracycline's, aminoglycosides etc.

\section{SECONDARY METABOLITES}

These are small molecules which are organic in nature and are not essential for growth and development of the organism. They have ability to inhibit other living organisms by mechanism such as competition, self-defense and antagonism to occupy the later's niche and consume its food. Many secondary metabolites from fungi are produced by plant endophytic and pathogenic fungi which exhibit broad spectrum activity with some of them with high microbial activity against human pathogens. Even marine fungi are explored for isolation of antibiotics even though they are underrepresented resource of available natural products. $^{4}$

\section{History of bioactive secondary metabolites from fungi}

Beneficial properties of ergot have not been recognized due to ill-fated incidents such as ergotism epidemic in $944-1000 \mathrm{AD}$ in which half of the population of Aquitaine of France died. ${ }^{5,6}$ First medical use of ergot for quickening child birth was in 1582. This has paved the way in the synthesis of LSD which has again got undermined because the compound has been used as an illicit recreational drug due to its hallucinogenic properties. ${ }^{7}$ At present, ergot alkaloids obtained from Claviceps purpurea gave lead to many semisynthetic derivatives for their wide range of therapeutic benefits in treatment of cancer, parkinson's disease and for its synergistic antimicrobial activities.

The identification of penicillin, the first antibiotic isolated from Penicillium notatum discovered by Alexander Fleming. This was milestone and breakthrough in drug discovery. ${ }^{8}$ The discovery and development of penicillin changed the quality of human life by paving a way for discovery of plethora of antibacterial compounds of which majority were isolated from Saccharomyces and Actinomycetes. ${ }^{9}$

Ongoing discovery of natural antimicrobials faced an obstacle due to rise of multidrug resistant pathogens. Antimicrobial resistance has 
developed due to green revolution during (1950-1970) which is based on chemicals to control pathogens in plant and animal production. ${ }^{10}$ This indirectly created a constant need for discovery of newer antibiotics in cost effective manner. Production of natural antimicrobials is only option before scientists to produce them in cost effective way within less time. This can be done only when micro-organisms like fungi are selected.

\section{MALARIA PARASITE AND PLASMODIUM}

Malaria is still serious threat to human society in various parts of tropics and subtropics. Aneskmate in 2016 tells that about 216 million malaria cases and deaths for about 445,000 occurred around the world. ${ }^{11}$ WHO has stated that resistance has already developed against the available antimalarial drug and mosquito vectors have become resistant to insecticides across the regions specified in WHO. ${ }^{11}$

The most affected population belong to tropical and subtropical regions of world especially the southeast Asia and sub Saharan Africa where $80 \%$ of malaria positive causes are due to Plasmodium falciparum. ${ }^{12}$ WHO report 2015 stated that more than 214 million of new cases were registered with about 4,38,000 deaths even after deployment of efforts to control it by providing access to preventive and curative measures. ${ }^{13}$

Researchers stated that eradication strategies which once were effective are also unsuccessful primarily due to complex life cycle of plasmodium and the emergence of drug resistant strains of it. ${ }^{14}$ Antimalarial drugs will benefit the therapy of malaria if they are with diverse mechanisms of action and if used in combination can decrease the drug resistance. This can only be achieved by rigorous search for novel antimalarial.

Novel effective and affordable treatments against malaria can be obtained from natural products. Clardy and Walsh (2004) stated that natural products have better chances of becoming effective drugs than de novo designed and chemically synthesized molecules. ${ }^{15}$ This can explained by the fact that - molecules produced by living organisms are the products formed as a result of long periods of biological evolution during which they have been exposed biological milieu such as proteins, nucleic acids and bio membranes.

\section{Malarial parasite and its life cycle}

Plasmodium species causes malaria. It is a digenetic parasite where it completes its life cycle in two hosts. Primary host is humans where asexual reproduction occurs and secondary host is female anopheles mosquito in which sexual reproduction. There are four species of malaria basically causing different types of malaria.

\begin{tabular}{cccc}
\hline S.No & $\begin{array}{c}\text { Species of } \\
\text { Plasmodium }\end{array}$ & Type of Malaria & $\begin{array}{c}\text { Fever relapse } \\
\text { after every }\end{array}$ \\
\hline 1. & P. vivax & Benign tertian malaria & $3^{\text {rd }}$ day \\
2. & P. ovale & Mild tertian malaria & $3^{\text {rd }}$ day \\
3. & P. malariae & Quartan malaria & $4^{\text {th }}$ day \\
4. & P. falciparum & Malignant tertian malaria & $3^{\text {rd }}$ day \\
\hline
\end{tabular}

Identification of targets of drug action is an important step for treating any infectious disease. Similarly a close observation of life cycle of any parasite will throw light on discovery of drugs which can target specific step in its life cycle. Life cycle of malaria parasite can be easily understood from the bite of female anopheles mosquito to healthy human. Plasmodium shuffles between hosts (humans) through the mosquito (female anopheles). ${ }^{16}$ Upon the bite of female anopheles mosquito, the mosquito sporozoites from the mosquito are released into human's blood. Sporozoite after setting in hepatocytes undergo schizogony and eventually forms merozoites. ${ }^{17}$

Merozoites of hepatic cycle infect the RBC and pass through different stages such as signet-ring stage, amoeboid stage and eventually transforms into erythrocytic schizont just before the bursting of RBC. Released merozoites from this stage again attack a new RBC and the cycle continues until there is no availability of fresh RBC. ${ }^{18}$ Few of the merozoites in this repeating cycle will form gametocytes which continue to circulate within the blood stream until there is bite of female anopheles mosquito for a blood meal. Release of haemozoin into blood during erythrocytic cycle causes fever and relapse for every 24-72 hr of time based on the type of malarial parasite.

Even though the best antimicrobial drug is one which can target stages of hepatic, erythrocytic and gametocyte stages, most of the currently available antimalarial are targeting the stages of erythrocytic cycle. ${ }^{19}$ As there is no complete eradication of malaria from the world, the parasite keeps on evolving by developing resistance to broadly used antimalarial. This has created requirement for novel antimalarial. Search for antimalarial lead compounds from natural resources may give unique options of molecules particularly the fungi

\section{DISCUSSION}

Molecular diversity in biosynthetic pathways in fungi makes it an excellent source of antimalarial lead compounds which has a power to alter biological process. ${ }^{20}$ Fungi represents one fourth of all recognized bioactive products and exhibit a source for the search of diverse compounds with wide spectrum of activities such as antileishmanial, antibacterial, anticancer and antimalarial. ${ }^{21}$

Natural products are a consistent source for developing antimalarial drugs which is best explained by quinine and artemesisnin from medicinal plants. Microbes are another group of living organisms which are highly diverse. Unfortunately, studies on microbes revealed that only $1 \%$ of bacteria and $5 \%$ of fungi have been characterized and the remaining microbes are unexplored for their potential to generate new drugs against many diseases. ${ }^{22}$

In this review, we have included many reprints on antimalarial from different sources such as- marine fungi, endophytic fungi and works on the extracts of plants for antimalarial principles. Following are excerpts of molecules isolated/studied from fungi and plants for antimalarial drug screening.

\begin{tabular}{ccccc}
\hline S. No & Source & Compound or Nucleus or extract studied & Antimicrobial activity \\
\hline 1 & Neosartorya spinosa & indole-quinazoline alkaloid tryptoquivaline & Activity against Plasmodium species \\
2 & Septoria pistaciarum & alkaloid $111 ; 1,4$-dihydroxy-5-phenyl-2- & Activity against Plasmodium falciparum \\
pyridinone skeleton & 22 \\
3 & Pyrenochaetopsis sp. & decalin-tetramic acid metabolite phomasetin & Activity against Plasmodium falciparum \\
& & $(155)$ & \\
4 & Penicillium copticola PSURSPG138 & eremophilane sesquiterpenoids porogen & Activity against Plasmodium falciparum \\
5 & Phomopsis archeri & aromatic sesquiterpenephomoarcherin B (172) & antiplasmodial activity
\end{tabular}




\begin{tabular}{|c|c|c|c|c|}
\hline 6 & $\begin{array}{lrr}\text { Penicillium } & \text { sp. } \quad \text { FKI-4410 } \\
(\text { Penicillium viticola } & \text { sp. nov) fungus }\end{array}$ & $\begin{array}{l}\text { puberulic acid (352) and a new derivative } \\
\text { viticolin B (353) }\end{array}$ & Activity against P. berghei-infected mice & 27 \\
\hline 7 & Favolaschia tonkinensis & $\begin{array}{c}\beta \text {-methoxyacrylate derivatives, } \\
\text { 9-methoxystrobilurins A, B and G (357-359) } \\
\text { and oudemansin B (360) }\end{array}$ & Activity against Plasmodium falciparum strain & 28 \\
\hline 8 & $\begin{array}{l}\text { Torrubiella sp. BCC } 28517 \\
\text { (leafhopper pathogenic fungus) }\end{array}$ & dimericanthraquinone, torrubiellin B (392) & Antiplasmodial activity & 29 \\
\hline 9 & Mycosphaerella sp. F2140 & Compound 405 (cercosporin analogue) & & 30,31 \\
\hline 10 & Chaetomium longirostre. & $\begin{array}{l}\text { azaphilones, longirostrerone A (411) and C } \\
\text { (412) }\end{array}$ & & 32 \\
\hline 11 & Annona muricata $\mathrm{L}$. & Ethyl acetate extract & $\begin{array}{c}\text { chloroquine-sensitive } \mathrm{Pf} 3 \mathrm{D} 7 \text {, chloroquine- } \\
\text { resistant PfINDO and PfDd2 strains of } P . \\
\text { falciparum }\end{array}$ & 33 \\
\hline 12 & Symphonia globulifera & ethyl acetate extract & $\begin{array}{l}\text { against the chloroquine-resistant } P \text {. falciparum } \\
\text { INDO (PfINDO) strain }\end{array}$ & 34 \\
\hline 13 & Ganoderma lucidum & $50 \%$ ethanol & $\begin{array}{l}\text { survival rate of mice infected with P. berghei } \\
\text { and the inhibition of the parasite growth }\end{array}$ & 35 \\
\hline 14 & Nemania sp. (Xylariaceae) & EtOAc extract & $\begin{array}{c}\text { against chloroquine-sensitive (D6) and } \\
\text { chloroquine-resistant (W2) strains of P. } \\
\text { falciparum }\end{array}$ & 36 \\
\hline 15 & $\begin{array}{l}\text { Diaporthemiriciae } \\
\text { Endophytic fungi }\end{array}$ & epoxycytochalasin H (419) & antiplasmodial activity & 37 \\
\hline 16 & Paecilomyces sp. SC0924 & $\begin{array}{l}\beta \text {-resorcylic acid lactones (RALs, Fig. 57) } \\
\text { paecilomycins A (434), E (435), F (436), } \\
\text { together with aigilomycin B (437) and } \\
\text { aigialomycin F ( } 438\end{array}$ & Antimalarial activity & 38 \\
\hline 17 & $\begin{array}{l}\text { Fusarium sp an root endophytic } \\
\text { fungi on } \\
\text { Mentha longifolia }\end{array}$ & $\begin{array}{c}\text { Cyclodepsipeptide } \\
\text { 3-hydroxy-4-methylpentadecanoic acid moiety, } \\
\text { fusaripeptide A (446) }\end{array}$ & Antimalarial activity & 39 \\
\hline 18 & $\begin{array}{l}\text { Fusarium fujikuroi } \\
\text { Plant source }\end{array}$ & cyclic tetrapeptide, apicidin F (450), & Antimalarial activity & 40 \\
\hline 19 & Ancistrocladus ileboensis & Dioncophyllines & Plasmodium falciparum & 41 \\
\hline 20 & Ancistrocladus tectorius & Ancistrobenomines B\&C & $\begin{array}{c}\text { Plasmodium falciparum and Trypanosoma } \\
\text { brucei rhodesiense }\end{array}$ & 42 \\
\hline 21 & Ancistrocladus tectorius & shuangancistrotectorines & antiplasmodial activity & 43 \\
\hline 22 & Cassia siamea & cassiarins $\mathrm{G}, \mathrm{H}, \mathrm{J}$ and $\mathrm{K}$ & antiplasmodial activity & 44 \\
\hline 23 & Dehaasia longipedicellata & $\begin{array}{c}\text { morphinandienones, }(+) \text {-sebiferine, } \\
(-) \text {-milonine; aporphines, }(-) \text {-boldine, }(-) \\
\text {-norboldine;benzyl isoquinoline, }(-) \text {-reticuline; } \\
\text { and bisbenzylisoquinoline, }(-) \text {-O-O- } \\
\text { dimethylgrisabine }\end{array}$ & Plasmodium falciparum & 45 \\
\hline 24 & Stephania venosa & $\begin{array}{l}\text { Stephanine, aporphine and one } \\
\text { tetrahydroprotoberberine }\end{array}$ & $\begin{array}{l}\text { antiplasmodial activity, } \\
\text { Anticancer activity }\end{array}$ & 46 \\
\hline 25 & Stephania rotunda & cepharanthine & antiplasmodial activity & 47 \\
\hline 26 & Cryptocary anigra & $\begin{array}{c}\text { (+)-N-methylisococlaurine, atherosperminine, } \\
\text { 2-hydroxy athersperminine and } \\
\text { noratherosperminine }\end{array}$ & antiplasmodial activity & 48 \\
\hline 27 & Ficus septica & $\begin{array}{l}\text { seco-phenanthroindolizine } \\
\text { phenanthroindolizine }\end{array}$ & Plasmodium falciparum & 49 \\
\hline 28 & Zanthoxylum heitzii & dihydronitidine, pellitorine and heitziquinone. & anti-malarials & 50 \\
\hline 29 & Geissospermum vellosii & $\begin{array}{c}\text { geissolosimine, geissospermine, geissoschizoline } \\
\text { and vellosiminol }\end{array}$ & anti-malarials & 51 \\
\hline
\end{tabular}




\begin{tabular}{|c|c|c|c|c|}
\hline 30 & $\begin{array}{l}\text { Aspidosperma excelsum } \\
\text { (stem bark) }\end{array}$ & Ethanolic extract & $\begin{array}{l}\text { chloroquineresistant P. falciparum (W2 strain) } \\
\text { and HepG2 cells, }\end{array}$ & 52 \\
\hline 31 & $\begin{array}{l}\text { Aspidosperma pyrifolium } \\
\text { stem bark, roots and leaves }\end{array}$ & $\begin{array}{l}\text { 95\% ethanol in a Soxhlet apparatus for } 72 \mathrm{~h} \text { and } \\
\text { then partitioned with different solvents and } \\
\text { acidified water to obtain an alkaloid- enriched } \\
\text { extract }\end{array}$ & Activity against P. berghei & 53 \\
\hline 32 & Periploca linearifolia stem bark & maceration in $80 \%$ methanol for $72 \mathrm{~h}$ & Antiplasmodial & 54 \\
\hline 33 & $\begin{array}{c}\text { Aloe megalacantha Baker } \\
\text { leaves }\end{array}$ & chloroform/ methanol (4:1) & Antimalarial activity & 55 \\
\hline 34 & Vernonia amygdalina Del. & $80 \%$ methanol extract of the leaves & parasitemia suppression & 56 \\
\hline 35 & Artemisia nilagirica (Clarke) Pamp. & $\begin{array}{l}\text { n-hexane, chloroform, petroleum ether, ethanol, } \\
\text { methanol and distilled water }\end{array}$ & Activity against Plasmodium falciparum & 57,58 \\
\hline 36 & Artemisia afra & acetone & $\begin{array}{c}\text { inhibits the viability of primarily late-stage } \\
\text { gametocytes of Plasmodium falciparum (NF54 } \\
\text { strain) }\end{array}$ & 59 \\
\hline 37 & $\begin{array}{l}\text { Erigeron floribundus (Kunth) } \\
\text { Schultz-Bip } \\
\text { Entire plant }\end{array}$ & ethanol/water $(70: 30)$ & Parasitemia supression & 60 \\
\hline 38 & $\begin{array}{l}\text { Echinops kebericho Mesfin } \\
\text { Fresh rhizomes }\end{array}$ & $70 \%$ methanol & $\begin{array}{l}\text { parasitemia suppressive effects against the } \\
\text { chloroquine- sensitive P. berghei strain ANKA }\end{array}$ & 61 \\
\hline 39 & $\begin{array}{l}\text { Adansonia digitata } \mathrm{L} . \\
\text { Stem bark }\end{array}$ & water or methanol & Plasmodium berghei & 62 \\
\hline 40 & $\begin{array}{l}\text { Commiphora africana } \\
\text { Stem bark and whole stem }\end{array}$ & $\begin{array}{l}\text { dichloromethane and methanol in a 1:1 ratio } \\
\qquad(\mathrm{v} / \mathrm{v})\end{array}$ & $\begin{array}{l}\text { antiplasmodial activity against D6 strain of } P \text {. } \\
\text { falciparum }\end{array}$ & 63 \\
\hline 41 & $\begin{array}{l}\text { Dichrostachys cinerea } \\
\text { Stem bark and whole stem }\end{array}$ & $\begin{array}{l}\text { dichloromethane and methanol in a 1:1 ratio } \\
\qquad(\mathrm{v} / \mathrm{v})\end{array}$ & $\begin{array}{l}\text { activity against both D6 and Dd2 strains of } P \text {. } \\
\text { falciparum }\end{array}$ & 63 \\
\hline 42 & $\begin{array}{l}\text { Azadirachta indica A. juss } \\
\text { Neem oil characterized by the } \\
\text { ECOCERT certificate (Biocert Italia } \\
\text { IT013BC041- ICEA } 264 \text { BC001) }\end{array}$ & Neem oil & $\begin{array}{l}\text { against W2, chloroquine (CQ)-resistant } \\
\text { and D10, chloroquinesensitive, strains of } P \text {. } \\
\text { falciparum }\end{array}$ & 64 \\
\hline 43 & $\begin{array}{c}\text { Curarea toxicofera (Wedd) Barneby } \\
\text { and Krukoff }\end{array}$ & $\begin{array}{l}\text { Decoction of plant fresh bark in boiling water } \\
\text { for } 30 \mathrm{~min}\end{array}$ & $\begin{array}{l}\text { In vitro antiplasmodial activity was evaluated on } \\
\text { P. falciparum FCR3 chloroquine-resistant strain }\end{array}$ & 65 \\
\hline 44 & $\begin{array}{l}\text { Keetia leucantha and Keetia venosa } \\
\text { Dried and ground twigs and leaves }\end{array}$ & dichloromethane & Antimalarial activity & 66 \\
\hline
\end{tabular}

\section{CONCLUSION}

The present review focused on antimalarial properties of natural products isolated from fungi. In present scenario, studies on isolation of fungal metabolite are more focused on marine fungi and endophytic fungi underestimating the potential of standard strains of pathogenic fungi. Considering large diversity of fungal species, only very few fungi have been studied and cultivated. This may account only to the surface of diverse world of fungi.

Vast majority of natural products with antimalarial potential remain yet to be identified. Fungi irrespective of its pathogenicity may produce highly potent and widely accepted natural metabolites if properly cultured at optimum environmental conditions. Using the existing information and most widely use target of plasmodium, we have selected a standard strain of fungi such as Malassezia furfur by cultivating it at different environmental conditions in a hope of finding potent antimalarial compounds.

\section{REFERENCES}

1. Alaa $A H A D$, Alyaa $A$, Ghadeer M. Antimicrobial agents' production by fungi isolates from the whisperers. Scien J Med Res. 2018;2(6):104-7.

2. Mondol MAM, Hee JSHJ. Antibacterial and Antiyeast Compounds from MarineDerived Bacteria. Marine Drugs. 2014;12(5):2913-21.

3. Newman DJ, Cragg GM. Natural products as sources of new drugs over the 30 years from 1981 to 2010. J Nat Prod. 2012;75(3):311-35.

4. Dorota J, Francois D. Selected fungal natural products with antimicrobial properties. Molecules. 2020;25(4):911.

5. Schiff PL. Ergot and its alkaloids. Am J Pharm Educ. 2006;70(5):98.

6. Dewick PM. Medicinal Natural Products. A Biosynthetic Approach. John Wiley and Sons. 2002.

7. Mukherjee J, Menge M. Progress and prospects of ergot alkaloid research. In New Products and New Areas of Bioprocess Engineering: Springer. 2000;1-20.

8. Ligon BL. Penicillin: Its discovery and early development. Semin Pediatr Infect 
Tehzeeb and Dhanabalan.: A Review on Natural Sources of Antimalarial

Dis WB Saunders. 2004;15.

9. Zhu H, Swierstra J, Wu C, Girard G, ChoiYH, WamelWV, et al. Eliciting antibiotics active against the ESKAPE pathogens in a collection of actinomycetes isolated from mountain soils. Microbiology. 2014;160(8):1714-25.

10. Pimentel D. Green revolution agriculture and chemical hazards. Sci Total Environ. 1996;188:S86-98.

11. World Health Organization (WHO). World Malaria Report; WHO: Geneva, Switzerland. 2017.

12. World Malaria Report License: CC BY-NC-SA 3.0 IGO; World Health Organization: Geneva, Switzerland. 2017.

13. WHO, World malaria report. 2015.

14. Wells TN. Discovering and developing new medicines for malaria control and elimination. Infect Disord Drug Targets. 2013;13(4):292-302.

15. Clardy J, Walsh C. Lessons from natural molecules. Nature. 2004;432(7019):82937.

16. World Malaria Report. WHO press, Geneva, Switzerland. 2012.

17. Prudencio M, Rodriguez A, Mota MM. The silent path to thousands of merozoites: The Plasmodium liver stage. Nat Rev Microbiol. 2006;4(11):849-56.

18. Tilley L, Dixon MWA, Kirk K. The Plasmodium falciparum-infected red blood cell. Int J Biochem Cell Biol. 2011;43(6):839-42.

19. Claessens A, Adams Y, Ghumra A, Lindergard G, Buchan CC, et al. A polymer of caffeyl alcohol in plant seeds Proc Natl Acad Sci USA. 2012;109:1772.

20. Kontnik R, Clardy JC. Codinaeopsin, an Antimalarial Fungal Polyketide. Org Lett. 2008;10(18):4149-51.

21. Nighat F, Syed AM, Muneer AQ, Zia US, Abida KK, Aneela M, et al. Fungal metabolites and antimalarial drug discovery: A Review. Acta Pol Pharm: Drug Res. 2017;74(5):1327-41.

22. Strobel GA, Daisy B. Bioprospecting for microbial endophytes and their natural products. Microbiol Mol Biol Rev. 2003;67(4):491-502.

23. Rajachan OA, Kanokmedhakul K, Sanmanoch W, Boonlue S, Hannongbua S, Saparpakorn $\mathrm{P}$, et al. Chevalone $\mathrm{C}$ analogues and globoscinic acid derivatives from the fungus Neosartory aspinosa KKU-1NK1. Phytochemistry. 2016;132:6875.

24. Kumarihamy M, Fronczek FR, Ferreira D, Jacob M, Khan SI, Nanayakkara ND. Bioactive 1,4-dihydroxy-5-phenyl-2-pyridinone alkaloids from Septoriapistaciarum. J Nat Prod. 2010;73(7):1250-3.

25. Nogawa T, Kato N, Shimizu T, Okano A, Futamura $Y$, Takahashi $S$, et al. Wakodecalines $A$ and $B$, new decaline metabolites isolated from a fungus Pyrenochaetopsis sp. RK10-F058. J Antibiot. 2018;71(1):123-8.

26. Daengrot C, Rukachaisirikul V, Tansakul C, Thongpanchang T, Phongpaichit $\mathrm{S}$, Bowornwiriyapan $\mathrm{K}$, et al. Eremophilane sesquiterpenes and diphenyl thioethers from the soil fungus Penicillium copticola PSURSPG138. J Nat Prod. 2015;78(4):615-22.

27. Hemtasin C, Kanokmedhakul S, Kanokmedhakul K, Hahnvajanawong C, Soytong K, Prabpai S, et al. Cytotoxic pentacyclic and tetracyclic aromatic sesquiterpenes from Phomopsisarcheri. J Nat Prod. 2011;74(4):609-13.

28. Iwatsuki M, Takada S, Mori M, Ishiyama A, Namatame M, Nishihara TA, et al. In vitro and in vivo antimalarial activity of puberulic acid and its new analogs, viticolins A-C, produced by Penicillium sp. FKI-4410. J Antibiot. 2011;64(2):183.

29. Kornsakulkarn J, Thongpanchang C, Chainoy R, Choowong W, Nithithanasilp S, Thongpanchang T. Bioactive metabolites from cultures of basidiomycete Favolaschiaton kinensis. J Nat Prod. 2010;73(4):759-62.

30. Isaka M, Palasarn S, Tobwor P, Boonruangprapa T, Tasanathai K. Bioactive anthraquinone dimers from the leafhopper pathogenic fungus Torrubiella $\mathrm{sp}$. BCC 28517. J Antibiot. 2012;65:571.

31. Moreno E, Varughese T, Spadafora C, Arnold AE, Coley PD, Kursar TA, et al. Chemical constituents of the new endophytic fungus Mycosphaerella $\mathrm{sp}$. novds and their anti-parasitic activity. Nat Prod Commun. 2011;6:835.

32. Kumarihamy M, Khan SI, Jacob M, Tekwani BL, Duke SO, Ferreira $D$, et al. Antiprotozoal and antimicrobial compounds from the plant pathogen Septoriapistaciarum. J Nat Prod. 2012;75(5):883-9.

33. Panthama N, Kanokmedhakul S, Kanokmedhakul K, Soytong K. Cytotoxic and antimalarial azaphilones from . J Nat Prod. 2011;74(11):2395-9.

34. Toghueo RMK, Kemgne EAM, Eke P, Kanko MIM, Dize D, Sahal D, et al. Antiplasmodial potential and GC-MS fingerprint of endophytic fungal extracts derived from Cameroonian Annona muricata. J Ethnopharmacol 2019;235:11121.

35. Ateba JET, Toghueo RMK, Awantu AF, Mba'ning BM, Gohlke S, Sahal D, et al. Antiplasmodial properties and cytotoxicity of endophytic fungi from Symphonia globulifera (Clusiaceae). J Fungi. 2018;4(2):70.

36. Oluba OM. Ganoderma terpenoid extract exhibited anti-plasmodial activity by a mechanism involving reduction in erythrocyte and hepatic lipids in Plasmodium berghei infected mice. Lipids Health Dis. 2019;18(1):12.

37. Kumarihamy M, Ferreira D, JrCroom EM, Sahu R, Tekwani BL, Duke SO, et al. Antiplasmodial and cytotoxic cytochalasins from an endophytic fungus, Nemania sp. UM10M, isolated from a diseased Torreya taxifolia leaf. Molecules. 2019;24(2):777.
38. Ferreira MC, Cantrell CL, Wedge DE, Gonçalves VN, Jacob MR, Khan S, et al. Antimycobacterial and antimalarial activities of endophytic fungi associated with the ancient and narrowly endemic neotropical plant Vellozia gigantea from Brazil. Mem Inst Oswaldo Cruz. 2017;112(10):692-7.

39. Xu L, He Z, Xue J, Chen X, Wei X. $\beta$-Resorcylic acid lactones from a Paecilomyces fungus. J Nat Prod. 2010;73(5):885-9.

40. Ibrahim SR, Abdallah HM, Elkhayat ES, AlMusayeib NM, Asfour HZ, Zayed MF, et al. Fusaripeptide A: New antifungal and anti-malarial cyclodepsipeptide from the endophytic fungus Fusarium sp. J Asian Nat Prod Res. 2018;20(1):75-85.

41. Bargen VKW, Niehaus EM, Bergander K, Brun R, Tudzynski B, et al. Structure elucidation and antimalarial activity of apicidin F: An apicidin-like compound produced by Fusarium fujikuroi. J Nat Prod. 2013;76(11):2136-40.

42. Li J, Seupel R, Feineis D, Mudogo V, Kaiser M, Brun R, et al. DioncophyllinesC2, $\mathrm{D} 2$ and $\mathrm{F}$ and related naphthyl isoquinoline alkaloids from the Congolese liana Ancistro cladusileboensis with potent activities against Plasmodium falciparum and against multiple myeloma and leukemia cell lines. J Nat Prod. 2017;80(2):443-58.

43. Bringmann G, Seupel R, Feineis D, Xu M, Zhang G, Kaiser M, et al. Antileukemic ancistro benomine $B$ and related 5,1'-coupled naphthyl isoquinoline alkaloids from the Chinese liana Ancistro cladustectorius. Fitoterapia. 2017;121:76-85.

44. Xu M, Bruhn T, Hertlein B, Brun R, Stich A, Wu J, et al. Shuangan cistrotectorines A-E, dimeric naphthyl isoquinoline alkaloids with three chiral biaryl axes from the Chinese plant Ancistro cladustectorius. Chem Eur J. 2010;16(14):4206-16.

45. Deguchi J, Hirahara T, Hirasawa Y, Ekasari W, Widyawaruyanti A, Shirota O, et al. New tricyclic alkaloids, cassiarins G, H, J and K from leaves of Cassia siamea. Chem Pharm Bull. 2012;60(2):219-22.

46. Zahari A, Cheah FK, Mohamad J, Sulaiman SN, Litaudon M, Leong KH, et al. Antiplasmodial and antioxidant isoquinoline alkaloids from Dehaasia longipedicellata. Planta Med. 2014;80(7):599-603.

47. Le PM, Srivastava V, Nguyen TT, Pradines B, Madamet M, Mosnier J, et al. Stephanine from Stephania venosa (Blume) Spreng showed effective antiplasmodial and anticancer activities, the latter by inducing apoptosis through the reverse of mitotic exit. Phytother Res. 2017;31(9):1357-68.

48. Desgrouas C, Chapus C, Desplans J, Travaille C, Pascual A, Baghdikian B, et al. In vitro antiplasmodial activity of cepharanthine. Malar J. 2014;13(1):327.

49. Nasrullah AA, Zahari A, Mohamad J, Awang K. Antiplasmodial alkaloids from the bark of Cryptocaryanigra (Lauraceae). Molecules. 2013;18(7):8009-17.

50. Kubo M, Yatsuzuka W, Matsushima S, Harada K, Inoue $Y$, Miyamoto $H$, et al. Antimalarial phenanthroindolizine alkaloids from Ficus septica. Chem Pharm Bull. 2016;64(7):957-60.

51. Goodman CD, Austarheim I, Mollard V, Mikolo B, Malterud KE, Fadden Mc GI, et al. Natural products from Zanthoxyl umheitzii with potent activity against the malaria parasite. Malar J. 2016;15(1):481

52. Mbeunkui F, Grace MH, Lategan C, Smith PJ, Raskin I, Lila MA. In vitro antiplasmodial activity of indole alkaloids from the stem bark of Geissospermum vellosii. J Ethnopharmacol. 2012;139(2):471-7.

53. Nascimento DMS, Pina NDPV, Silva DASB, Gomes LFDS, Vasconcellos DF, Brandão GC, et al. In vitro antiplasmodial activity and identification, using tandem LC-MS, of alkaloids from Aspidosperma excelsum, a plant used to treat malaria in Amazonia. J Ethnopharmacol. 2019;228:99-109.

54. Ceravolo IP, Zani CL, Figueiredo FJB, Kohlhoff M, Santana AEG, Krettli AU. Aspidosperma pyrifolium, a medicinal plant from the Brazilian caatinga, displays a high antiplasmodial activity and low cytotoxicity. Malar J. 2018;17(1):436.

55. Belay WY, Endale GA, Wubneh ZB. Antimalarial activity of stem bark of Periploca linearifolia during early and established Plasmodium infection in mice. Evid Based Complement Alternat Med. 2018;4169397.

56. Hintsa G, Sibhat GG, Karim A. Evaluation of antimalarial activity of the leaf latex and TLC isolates from Aloe megalacantha Baker in Plasmodium berghei infected mice. Evid Based Complement Alternat Med. 2019;6459498

57. Bihonegn T, Giday M, Yimer G, Animut A, Sisay M. Antimalarial activity of hydromethanolic extract and its solvent fractions of Vernonia amygdalina leaves in mice infected with Plasmodium berghei. SAGE Open Med. 2019;7:2050312119849766

58. Panda S, Rout JR, Pati P, Ranjit M, Sahoo SL. Antimalarial activity of Artemisia nilagirica against Plasmodium falciparum. J Parasit Dis. 2018;42(1):22-7.

59. Panda SK, Das R, Leyssen P, Neyts J, Luyten W. Assessing medicinal plants traditionally used in the Chirang Reserve Forest, Northeast India for antimicrobial activity. J Ethno Pharmacol. 2018;225:220-33.

60. Moyo P, Kunyane P, Selepe MA, Eloff JN, Niemand J, Louw Al, et al. Bioassayguided isolation and identification of gametocytocidal compounds from Artemisia afra (Asteraceae). Malar J. 2019;18(1):65.

61. Tepongning RN, Mbah JN, Avoulou FL, Jerme MM, Ndanga EK, Fekam FB. Hydroethanolic extracts of Erigeron floribundus and Azadirachta indica reduced Plasmodium berghei parasitemia in Balb/c mice. Evid Based Complement Alternat Med. 2018;5156710

62. Biruksew A, Zeynudin A, Alemu Y, Golassa L, Yohannes M, Debella A, et al. Zingiber officinale Roscoe and Echinops kebericho Mesfin showed antiplasmodial activities against Plasmodium berghei in a dose-dependent manner in Ethiopia. Ethiop J Health Sci. 2018;28(5):655-64. 
63. Adeoye AO, Bewaji CO. Chemopreventive and remediation effect of Adansonia digitata L. baobab (Bombacaceae) stem bark extracts in mouse model malaria. J Ethnopharmacol. 2018;210:31-8.

64. Kweyamba PA, Zofou D, Efange N, Assob JN, Kitau J, Nyindo M. In vitro and in vivo studies on anti-malarial activity of Commiphora africana and Dichrostachys cinerea used by the Maasai in Arusha region, Tanzania. Malar J. 2019;18(1):119.

65. Cesa S, Sisto F, Zengin G, Scaccabarozzi D, Kokolakis AK, Scaltrito MM, et al.
Phytochemical analyses and pharmacological screening of neem oil. S Afr J Bot. 2019;120:331-7.

66. Rodríguez YV, Arias MH, García JO, Deharo E, Garavito G. Pharmacological activity of Curarea toxicofera in combination with classical antimalarial treatments. J Ethnopharmacol. 2018;222:288-94.

67. Freire RT, Bero J, Beaufay C, Selegato DM, Coqueiro A, Choi YH, QuetinLeclercq J Identification of antiplasmodial triterpenes from Keetia species using NMR-based metabolic profiling. Metabolomics. 2019;15(3):27.

Article History: Submission Date : 23-08-2020; Revised Date : 18-09-2020; Acceptance Date : 03-10-2020.

Cite this article: Tehzeeb, Dhanabalan. A Review on Natural Sources of Antimalarials: Fungi and Plants. Int. J. Pharm. Investigation, 2020;10(4):417-22. 